\title{
LABORATORY STUDIES OF ALLELOPATHIC EFFECTS OF JUNIPERUS VIR GINIANA L. ON FIVE SPECIES OF NATIVE PLANTS
}

\author{
Erica A. Corbett \\ Andrea Lashley \\ Department of Biological Sciences \\ Southeastern Oklahoma State University \\ Durant, OK 74701 \\ ecorbett@se.edu
}

Keywords: allelopathy, prairie restoration, eastern redcedar, germination, encroaching

\begin{abstract}
Juniperus virginiana L. (eastern redcedar) is known as an encroaching native plant species. It poses particular problems in the Great Plains, where fire suppression in the $20^{\text {th }}$ century has led to the expansion of its population and the area it affects. There is some evidence that the genus Juniperus contains members that are allelopathic; work with western species of juniper have demonstrated negative effects of litter on seedling growth. We established laboratory experiments to test the effect of a water leachate of eastern redcedar litter $(100 \mathrm{~g}$ litter per liter DI water; steeped $8 \mathrm{~h}$ ) and eastern redcedar litter on the growth and germination of five native herbaceous species. We saw no clear negative effect of leachate or litter; in fact, there is limited evidence that the leachate increased percent germination, and the presence of litter may have led to greater height growth in inland sea-oats. There was no evidence of the litter or leachate acidifying the soil, at least over the short course of the experiment. It is possible the main negative effect of the presence of eastern redcedar on herbaceous species is through light or nutrient competition by mature trees. We are repeating this study in a field setting.
\end{abstract}

\section{INTRODUCTION}

Juniperus virginiana L. (eastern redcedar), while a native plant in the U.S., has encroached throughout much of the Great Plains region following fire suppression and extensive land-use changes in the $20^{\text {th }}$ century (van Els et al. 2010; Linneman et al. 2011). Eastern redcedar had invaded 600,000 acres in Oklahoma by 1950; that number had increased to 1,400,000 acres in 1985 (Engle et al. 1987). It can change a prairie into a closed woodland in less than 100 years (Limb et al. 2010) and is considered a weed tree throughout much of its range, including Oklahoma. Eastern redcedar tends to invade both abandoned land and high-diversity, non-degraded native grassland because of high seed production and rapid seed dispersal (Holthuizen and Sharik 1984; Linneman et al. 2011). Juniperus species in general are a common woody invader in many grassland ecosystems (Limb et al. 2010; Alford et al. 2012). Eastern redcedar can also affect soil properties, raising $\mathrm{pH}$ and leading to an increase in calcium content (Pierce and Reich 2010). When junipers come to dominate a site, they greatly reduce the ground cover layer (Horman and Anderson 2003). The reduction of ground cover is evidenced by the bare patches that often develop below its crown and dripline; there are five possible contributing factors (not 
necessarily mutually exclusive) for this, listed by Horman and Anderson (2003):

1. The litter (bark, needles, shed branches, cones) of the cedar trees change soil $\mathrm{pH}$ and change its properties to prevent germination or growth of seeds.

2. The shade cast by the crown of the tree is deep enough to hinder survival of herbaceous plants and prevents germination.

3. The tree competes strongly for water with other species.

4. The depth of the litter smothers or prevents water from reaching herbaceous plants and seedlings.

5. The tree itself (roots or litter) is allelopathic and hinders seedling germination and/or survival.

Many western juniper species show this sort of reduction: Horman and Anderson (2003) demonstrated that Utah juniper (Juniperus osteosperma (Torr.) Little) litter did seem to have a negative effect on seedling growth and survival but more from the standpoint of drying than of allelopathy (i.e., the litter prevented the seeds from properly imbibing water in order to germinate). Schott and Pieper (1985) found that shading by one-seeded juniper (Juniperus monosperma (Engelm.) Sarg.) in New Mexico had a major effect on grass growth, and that litter and allelopathy had secondary effects. Ashe juniper (Juniperus ashei J. Buchholz) also has a zone of reduced understory growth beneath its dripline, and furthermore, growth of vegetation may be stunted in areas where junipers were present but had been removed (Yager and Smeins 1999). However, Engle et al. (1987) observed that the zonation noted around the base of western juniper species was not as clear around eastern redcedar. They examined the effect of eastern redcedar on herbage standing crop in tallgrass prairie. Their measurements were taken $1 \mathrm{~m}$ and $3 \mathrm{~m}$ beyond the dripline of trees. They demonstrated an effect of proximity to the tree; biomass of herbaceous vegetation was reduced close to the dripline of the cedar. They concluded this was a result of shading or possibly water competition rather than allelopathy. Also, in general, the effect on herbaceous vegetation under eastern redcedar in Oklahoma was less than the effect under other Juniperus species in the arid southwest (Engle et al. 1987). Alford et al. (2012) demonstrated that removal of eastern redcedar from grassland areas in Oklahoma increased herbaceous plant species diversity and biomass, likely because of reduced competition for light. The effect was stronger the more heavily-invaded the area had been.

Van Els et al. (2010) proposed possible changes J. virginiana could cause in grassland: increased litter depth, increased soil $\mathrm{pH}$, changes in soil $\mathrm{N}$ and $\mathrm{C}$ balance, and decreased light availability. Apparently redcedars increase, rather than decrease, soil $\mathrm{pH}$, unlike the litter of some other conifers. Van Els et al. (2010) also proposed that the effects of redcedar encroachment would be different on prairie than in forest. Smith and Stubbendieck (1990) determined that in tallgrass prairie, grass biomass was reduced underneath redcedar canopy, and that water content under the tree canopy was reduced. They concluded competition for soil water was the most important factor. Linnemann et al. (2011) demonstrated in a field experiment that removal of redcedar litter and trees increased herbaceous cover and species diversity, with removal of the trees having a bigger effect on forb and prairie grass cover. In a laboratory experiment, Stipe and Bragg (1989) demonstrated that only one prairie species among those studied (Coreopsis palmata Nutt.) showed a statistically significant decrease in germination when grown in soil from underneath redcedar. However, the seeds were watered with tapwater, so there was no further influence of litter after its removal.

Our objectives for this study were to determine to what extent eastern redcedar 
affected selected prairie species. In particular, we were interested in the possible effects of remaining eastern redcedar litter in areas where prairie restorations might be attempted. We examined litter and leachate; future studies will examine the effects of dripline, proximity, and shading on plant growth. In this study, we focus on determining whether leachate from litter reduces prairie plant germination and growth. We hypothesize that there will be reductions in germination and/or growth of the selected plant species (two prairie grasses, two prairie forbs, one woodland grass) when watered with leachate from redcedar leaves and that the presence of litter will make that effect stronger.

\section{METHODS AND MATERIALS}

In early October 2016, approximately 30 pounds of Juniperus virginiana branches were collected from pastureland just outside of Durant, Oklahoma. These bags were transported to Southeastern Oklahoma State University and maintained at roughly $20^{\circ} \mathrm{C}$. On October 8, leachate was prepared: redcedar needles were picked clean of branches and woody material. One hundred grams of this "cedar litter" were steeped for $8 \mathrm{~h}$ in $1000 \mathrm{~mL}$ deionized water (similar to the $10 \%$ leachate as prepared by Horman and Anderson 2003). At the end of the time period, the leachate was filtered through a 50 mesh sieve, bottled, and frozen at $0^{\circ} \mathrm{C}$ until needed.

Natural soil was collected from a disturbed grassland on Lake Texoma, Bryan County, Oklahoma $\left(33.999687^{\circ} \mathrm{N}\right.$, $\left.-96.587678^{\circ} \mathrm{W}\right)$. The site was dominated by several species of panic-grasses (Dichanthelium), crowngrasses (Paspalum), and with forbs, Lespedeza cuneata (Dum. Cours.) G. Don (sericea lespedeza) and Rudbeckia birta L. (black-eyed Susan). There was a stand of Ulmus alata Michx. (winged elm) within $15 \mathrm{~m}$ of where the soil was collected. The soil is in the Boxville Fine Sandy Loam series (USDA 1978). Approximately the top $20 \mathrm{~cm}$ of soil was collected and transported to Southeastern Oklahoma State University.

Cone-tainers size SC-10 (21 cm deep and roughly $4 \mathrm{~cm}$ in diameter) (Ray Leach Company) were set up in racks. There was a total of four treatments and five species, and nine replicates of each species by treatment combination, resulting in 180 Cone-tainers. Each Cone-tainer was filled with soil, and a standard-sized marble (Cardinal Industries' "Marble Bonanza") was placed in the bottom of each Conetainer to allow for drainage and prevent excessive leakage of soil. Each Cone-tainer was planted with 2-3 seeds of one of the focal species. As the seeds germinated, excess individuals were removed to leave one plant per Cone-tainer. The focal species were: little bluestem (Schizachyrium scoparium (Michx.) Nash), Indian grass (Sorghastrum nutans (L.) Nash), inland sea-oats (Chasmanthium latifolium (Michx.) H.O. Yates), partridge-pea (Chamaecrista nictitans (L.) Moench), and black-eyed Susan. Seeds were purchased from Native American Seeds in Junction, Texas.

The racks of Cone-tainers were set under a fluorescent-light fixture having six fluorescent tubes (GE Plant and Aquarium 40 Watt T12 Warm Linear Fluorescent Tubes). These light fixtures were suspended from PVC frames so that the tubes were approximately $20 \mathrm{~cm}$ above the tops of the Cone-tainers. The lights were set on a timer to give a $14 \mathrm{~h}$ daylength. Two identical fluorescent fixtures were used because there was not enough room for both racks under a single fixture.

Four treatments were applied: Control $(10 \mathrm{ml}$ of deionized water once a week, no litter), Leachate only (10 $\mathrm{ml}$ of eastern redcedar leachate once a week), Litter only $(\sim 3 \mathrm{~cm}$ of eastern redcedar litter on top of soil surface), and Litter plus leachate $(\sim 3 \mathrm{~cm}$ of litter plus $10 \mathrm{ml}$ leachate once a week). Between treatments, all Cone-tainers were watered every second or third day (as 
needed, from examining the soil surface). Precise amounts of water given to each of the 180 Cone-tainers were not measured in these waterings; however, it was approximately the same quantity to each.

We monitored time-to-germination and percent germination of each species. At the end of the first run of the experiment (5 December 2016), we measured the height of each germinated grass individual or leaflength of the largest leaf for the forbs. We measured leaf growth because individual plants were too small to be weighed.

In January 2017, we began a second run of the experiment with a few changes. Because of high dormancy of inland seaoats, the seeds were subjected to $30 \mathrm{~d}$ of cold-wet stratification (between paper towels in a $5^{\circ} \mathrm{C}$ refrigerator) before planting. Additionally, partridge-pea seeds were scarified with 100 grit sandpaper before planting.

Fresh soil and cedar branches were collected from the same location as for the first experiment. In contrast to the first experiment, the soil was sieved prior to planting to give a more homogeneous substrate. Seeds were planted on 25 January 2017. Other procedures were the same as for the first experiment. The second experiment concluded on 11 April 2017, and the height of each grass and length of the longest leaf of each forb individual measured. The soil from replicates of each species and treatment combination was pooled, and a $20 \mathrm{~g}$ sample was analyzed for $\mathrm{pH}$.

We conducted a third study in spring 2017 examining the effects of cedar leachate on seed germination. The same five species were included in this study. Two treatments were applied: Control (distilled water only) and Leachate. Ten seeds from each of the five species were placed into separate petridishes between layers of filter paper. For each species, treatments were applied to six petri-dishes: three received distilled water and three received leachate. There were three replicates (of ten seeds each) for each species and each treatment. Petri dishes were maintained at room temperature and were watered as needed: control dishes were watered with deionized water, and treatment dishes with leachate. Both the distilled water and eastern redcedar leachate were stored at approximately $4^{\circ} \mathrm{C}$ and were applied to the seeds at this temperature. Germination percentage was recorded after $30 \mathrm{~d}$, and shoot extension and radicle length were measured. Inland sea-oats was dropped from further analysis because of low germination.

Analysis of the germination data was challenging because germination was typically low (Table 1). We used likelihoodratio chi-square analysis (G-test) based on number of seeds germinating. We tested the fall 2016 and spring 2017 experiments separately. For this test and all other statistical tests, we used an alpha level of 0.05 for significance. We also grouped all species for each treatment separately for the two experiments for analysis of overall effects across species. For the combined data, we tested the data for normality using a Shapiro-Wilk test. Where data were normal, we performed a one-way analysis of variance (ANOVA) on germination by treatment. When data were not normal, we performed Kruskal-Wallis analysis. We originally planned to use two-way ANOVA to test for treatment by species interactions in germination and growth. However, because germination was low overall and the species differed in growth form (grasses vs. forbs, one forb had compound leaves and the other had simple leaves), we chose instead to do a series of one-way ANOVAs. The soil pH data (2017 experiment only) were analyzed with a one-way ANOVA following a test for normality. For the petriplate experiment, we used chi-square and likelihood-ratio chi-square tests of germination percentages and Mann-Whitney U-tests on growth of individual species. Statistical analyses, including chi-square 
Table 1 Germination results for prairie plants in Cone-tainers subjected to leachate and litter treatments in 2016 and 2017. Control $=$ no litter, no leachate. Leachate $=$ leachate only. Litter $=$ litter only. Both = litter plus leachate. $\mathrm{LB}=$ little bluestem, $\mathrm{IG}=$ Indian grass, $\mathrm{SO}=$ inland sea-oats, $\mathrm{PP}=$ partridge-pea, and BS = black-eyed Susan. For all treatments, $\mathrm{n}=9$.

Experiment 1: Fall 2016

\begin{tabular}{|c|c|c|}
\hline Treatment & Species & Percent Germination \\
\hline Control & LB & 33.3 \\
\hline Control & IG & 55.6 \\
\hline Control & $\mathrm{SO}$ & 22.2 \\
\hline Control & PP & 0.0 \\
\hline Control & BS & 33.3 \\
\hline Leachate & $\mathrm{LB}$ & 22.2 \\
\hline Leachate & $\mathrm{IG}$ & 55.6 \\
\hline Leachate & $\mathrm{SO}$ & 22.2 \\
\hline Leachate & PP & 0.0 \\
\hline Leachate & BS & 77.8 \\
\hline Litter & $\mathrm{LB}$ & 66.7 \\
\hline Litter & IG & 66.7 \\
\hline Litter & $\mathrm{SO}$ & 11.1 \\
\hline Litter & PP & 11.1 \\
\hline Litter & BS & 22.2 \\
\hline Both & LB & 77.8 \\
\hline Both & IG & 77.8 \\
\hline Both & $\mathrm{SO}$ & 33.3 \\
\hline Both & PP & 0.0 \\
\hline Both & BS & 66.7 \\
\hline
\end{tabular}


Table 1 Continued

Experiment 2: Spring 2017

\begin{tabular}{lcc} 
Treatment & Species & Percent Germination \\
Control & LB & 11.1 \\
Control & IG & 66.7 \\
Control & SO & 77.8 \\
Control & PP & 11.1 \\
Control & BS & 44.4 \\
Leachate & LB & 55.6 \\
Leachate & IG & 77.8 \\
Leachate & SO & 88.9 \\
Leachate & PP & 11.1 \\
Leachate & BS & 88.9 \\
Litter & LB & 22.2 \\
Litter & IG & 33.3 \\
Litter & SO & 100.0 \\
Litter & PP & 0.0 \\
Litter & BS & 33.3 \\
Both & LB & 22.2 \\
Both & IG & 55.6 \\
Both & SO & 100.0 \\
Both & PP & 0.0 \\
Both & BS & 88.9 \\
& & \\
\hline
\end{tabular}


Table 2 Growth of four species under four treatments. Growth data is plant height (grasses) or length of longest leaf (forbs) at the end of the growing period. Control $=$ no litter, no leachate. Leachate $=$ leachate only. Litter $=$ litter only. Both $=$ litter plus leachate. $\mathrm{n}=$ sample size. Partridge-pea is not included as germination was too low (zero for three treatments).

Fall 2016

Treatment

Growth $(\mathrm{cm} \pm \mathrm{SE})$

Little Bluestem

Control

$10.6 \pm 2.6$

Leachate

$8.0 \pm 0.6$

Litter

$13.8 \pm 2.5$

Both

$10.2 \pm 0.4$

\section{Indian Grass}

Control

Leachate

Litter

Both

Control

Leachate

Litter

Both

Control

Leachate

Litter

Both
$12.7 \pm 2.0$

$21.3 \pm 4.5$

Inland Sea-oats

$13.9 \pm 6.4$

$$
9.5 \pm 1.0
$$

$6.0 \pm 0.0$

$10.6 \pm 2.0$

Black-eyed Susan

$2.8 \pm 0.7 \quad 3$

$1.8 \pm 0.2$

7

$2.6 \pm 0.4$

2

$3.5 \pm 0.1$
6 
Table 2 Continued

Spring 2017

Treatment

Growth $(\mathrm{cm} \pm \mathrm{SE})$

n

Little Bluestem

Control

Only one observation, no mean

1

Leachate

$13.3 \pm 1.9$

5

Litter

$17.7 \pm 4.0$

3

Both

$16.5 \pm 0.1$

2

\section{Indian Grass}

Control

$22.7 \pm 3.2$

6

Leachate

$18.8 \pm 2.6$

7

Litter

$24.5 \pm 3.9$

3

Both

$20.8 \pm 1.7$

5

Inland Sea-oats

Control

$9.2 \pm 0.9$

Leachate

$7.7 \pm 0.8$

8

Litter

$11.3 \pm 0.7$

9

Both

$12.0 \pm 0.8$

9

Black-eyed Susan

Control

Leachate

Litter

Both
$3.3 \pm 0.3$

$2.4 \pm 0.4$

$2.4 \pm 0.6$

$3.0 \pm 0.3$
2*

$5^{* *}$

3

8

*One individual germinated (total germinating $=3$ ) but died before maturity

**Three individuals germinated (total germinating $=8$ ) but died before maturity 


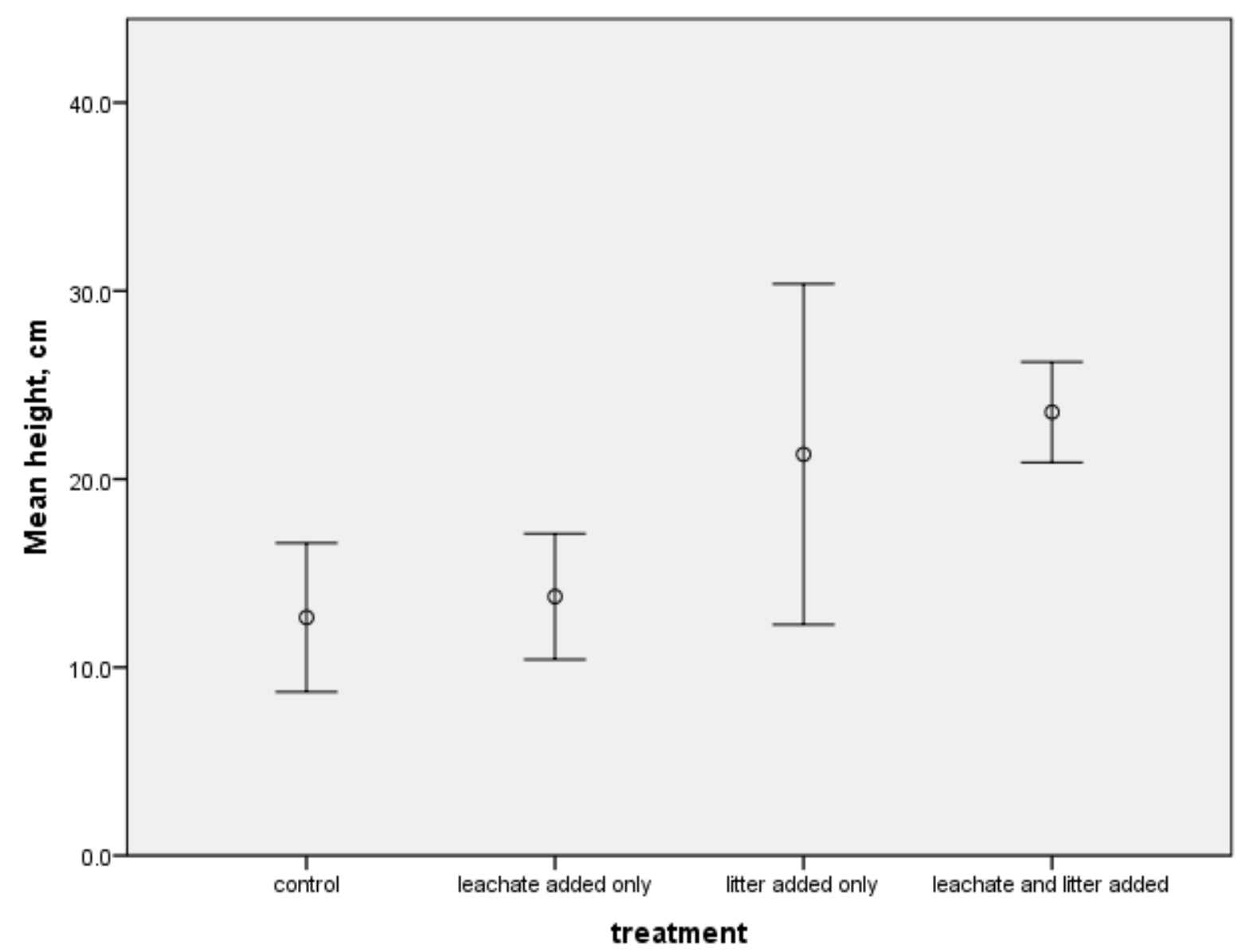

Error Bars: +/- 2 SE

Figure 1 Average height of Indian grass for four eastern redcedar treatments in fall 2016. Sample sizes: control, $n=4$; leachate, $n=5$; litter, $n=6$; litter plus leachate, $n=7$. Treatment significantly affected height, but no pairwise comparisons were significantly different in post hoc tests.

Erica A. Corbett and Andrea Lashley 


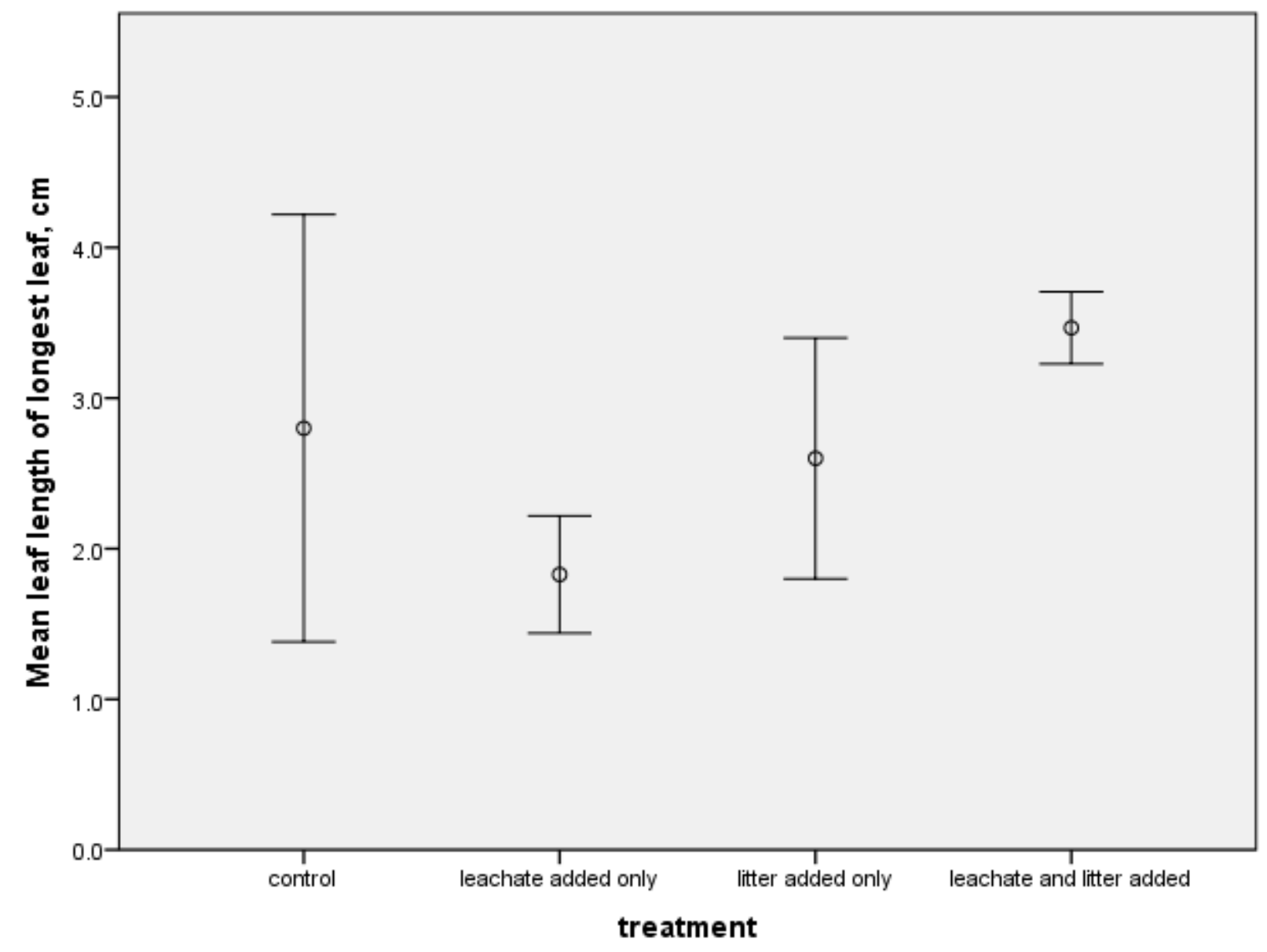

Error Bars: +/- 2 SE

Figure 2 Average leaf length of black-eyed Susan by treatment for fall 2016 data. Control, $n=3$; leachate treatment, $n=7$; litter treatment, $n=29$; litter plus leachate treatment, $n=6$. 
tests, ANOVAS, and Kruskal-Wallis tests, were performed using SPSS (IBM 2011).

\section{RESULTS}

\section{Fall 2016 germination and growth (Cone-tainer experiment 1)}

Germination percentages are shown in Table 1. Species-treatment combinations did not differ in germination percentages $(\mathrm{G}=9.161, \mathrm{df}=12, \mathrm{p}=0.689)$. To test treatment effects across species, we grouped the data for all species within each treatment. The data were not normal (Shapiro-Wilk test, $\mathrm{W}_{(20)}=0.899$, $\mathrm{p}=0.040)$. There was no significant difference in germination among treatments for all species grouped together (KruskalWallis test: $\left.\chi^{2}=5.077, \mathrm{df}=3, \mathrm{p}=0.166\right)$.

Growth measures (i.e., the longest leaf height on the grasses or the longest leaf on the forbs) are presented in Table 2. Partridge-pea had too few germinating individuals to analyze. We analyzed each species separately because of differences in growth form. Little bluestem data were not normal $\left(\mathrm{W}_{(18)}=0.853, \mathrm{p}=0.009\right)$ and showed no significant effect of treatment on growth $(G=4.879, \mathrm{df}=3, \mathrm{p}=0.181)$. Normality of Indian grass data could not be rejected $\left(\mathrm{W}_{(22)}=0.981, \mathrm{p}=0.927\right)$, and Indian grass showed a significant effect of treatment (ANOVA, $\left.\mathrm{F}_{(3,18)}=3.598, \mathrm{p}=0.034\right)$. There is a weak trend for litter application to result in greater height (Figure 1). However, this was not statistically significant in post-hoc tests. Normality of inland sea-oats data could not be rejected $\left(\mathrm{W}_{(8)}=0.878, \mathrm{p}=0.180\right)$, and inland sea-oats did not show a significant effect of treatment (ANOVA, $\left.\mathrm{F}_{(3,4)}=0.557, \mathrm{p}=0.671\right)$, perhaps because sample sizes were low due to poor germination. Normality of black-eyed Susan data could not be rejected $\left(\mathrm{W}_{(18)}=0.962\right.$, $\mathrm{p}=0.650)$, and black-eyed Susan showed a significant effect of treatment (ANOVA, $\left.F_{(3,4)}=7.63, p=0.003\right)$, but post-hoc tests did not find pairwise differences between treatments (Figure 2)

\section{Spring 2017 germination and growth (Cone-tainer experiment 2)}

For the spring germination results (see Table 1), again there was no significant relationship between treatment, species, and germination $(\mathrm{G}=6.190, \mathrm{df}=12, \mathrm{p}=0.906)$. After grouping species within treatment, differences among were not significant $\left(\chi^{2}=1.702, \mathrm{df}=3, \mathrm{p}=0.637\right)$.

For spring growth measures (Table 2), normality of little bluestem data could not be rejected $\left(\mathrm{W}_{(11)}=0.915, \mathrm{p}=0.277\right)$, and little bluestem showed no significant effect of treatment on growth (ANOVA, $\left.F_{(3,7)}=1.478, p=0.301\right)$. Normality of Indian grass data could not be rejected $\left(\mathrm{W}_{(21)}=0.979, \mathrm{p}=0.908\right)$, and Indian grass did not show a significant effect of treatment (ANOVA, $\mathrm{F}_{(3,7)}=0.687$, $\mathrm{p}=0.572)$. Normality of inland sea-oats data could not be rejected $\left(\mathrm{W}_{(34)}=0.972\right.$, $\mathrm{p}=0.518$ ), and inland sea-oats growth was affected significantly by treatment (ANOVA, $\mathrm{F}_{(3,30)}=6.211, \mathrm{p}=0.002$ ), with individuals in treatment 4 (litter plus leachate) growing larger (Student-NewmanKeuls test) than individuals in treatment 2 (leachate alone; Figure 3). Normality of black-eyed Susan data could not be rejected $\left(\mathrm{W}_{(18)}=0.945, \mathrm{p}=0.346\right)$, and growth of black-eyed Susan did not show a significant effect of treatment (ANOVA, $\left.\mathrm{F}_{(3,14)}=0.811, \mathrm{p}=0.509\right)$.

Normality of treatment $\mathrm{pH}$ (Table 3) could not be rejected $\left(\mathrm{W}_{(20)}=0.934\right.$, $\mathrm{p}=0.188)$. Treatments did not affect soil $\mathrm{pH}$ (ANOVA, $\mathrm{F}_{(3,16)}=1.355, \mathrm{p}=0.262$ ). 


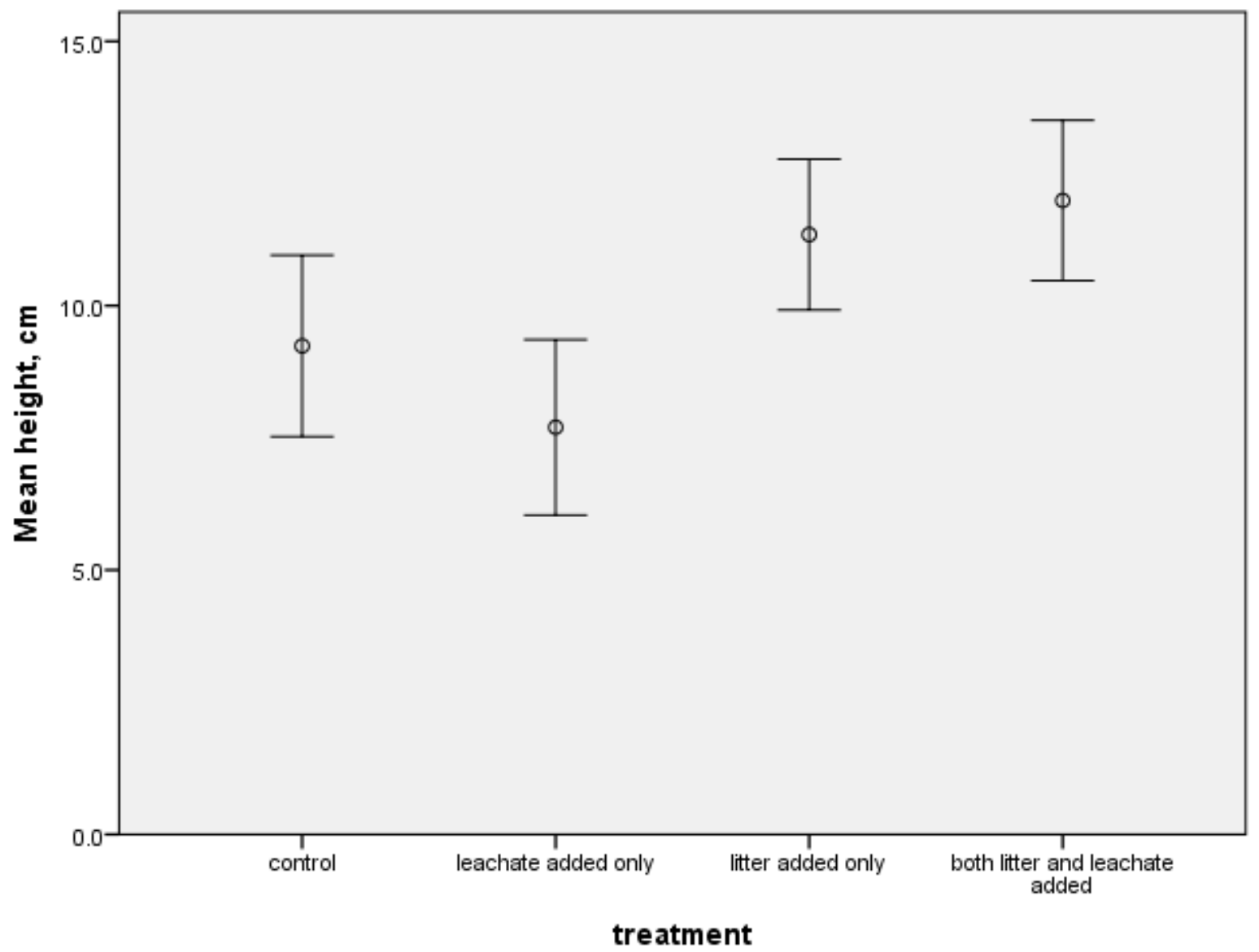

Error Bars: +/- 2 SE

Figure 3 Average height of inland sea-oats by treatment for spring 2017 data. Control, $\mathrm{n}=8$; leachate treatment, $n=8$; litter treatment, $n=9$; litter plus leachate treatment, $n=9$. 
Table 3 Soil pH for five species under five treatments in spring 2017 and means across species within treatment. Control $=$ no litter, no leachate. Leachate $=$ leachate only. Litter $=$ litter only. Both = litter plus leachate. $\mathrm{LB}=$ little bluestem, $\mathrm{IG}=$ Indian grass, $\mathrm{SO}=$ inland sea-oats, $\mathrm{PP}=$ partridge-pea, and BS = black-eyed Susan.

\begin{tabular}{|c|c|c|}
\hline Treatment & Species & $\mathrm{pH}$ \\
\hline Control & $\mathrm{LB}$ & 6.4 \\
\hline Control & IG & 6.2 \\
\hline Control & $\mathrm{SO}$ & 6.3 \\
\hline Control & PP & 6.1 \\
\hline Control & BS & 5.7 \\
\hline Mean $( \pm \mathrm{SE})$ & & $6.1 \pm 0.13$ \\
\hline Leachate & $\mathrm{LB}$ & 6.0 \\
\hline Leachate & IG & 6.0 \\
\hline Leachate & $\mathrm{SO}$ & 6.0 \\
\hline Leachate & PP & 6.1 \\
\hline Leachate & BS & 6.2 \\
\hline Mean $( \pm$ SE $)$ & & $6.1 \pm 0.04$ \\
\hline Litter & $\mathrm{LB}$ & 6.2 \\
\hline Litter & IG & 5.9 \\
\hline Litter & $\mathrm{SO}$ & 5.8 \\
\hline Litter & PP & 6.1 \\
\hline Litter & BS & 5.8 \\
\hline Mean $( \pm$ SE $)$ & & $6.0 \pm 0.08$ \\
\hline Both & $\mathrm{LB}$ & 6.0 \\
\hline Both & IG & 6.2 \\
\hline Both & $\mathrm{SO}$ & 6.2 \\
\hline Both & PP & 6.2 \\
\hline Both & BS & 6.2 \\
\hline Mean $( \pm \mathrm{SE})$ & & $6.2 \pm 0.04$ \\
\hline
\end{tabular}




\section{Germination in petri-dishes}

Species and treatment combinations differed in germination percentage (Table 4, chi-square $=42.897, \mathrm{df}=4, \mathrm{p}<0.001)$. This result was likely influenced by differences in germination of Indian grass (ca $27 \%$ for control vs. ca $37 \%$ for added leachate) and little bluestem (ca 10\% vs. 30\% ). In both cases, the presence of the cedar leachate seemed to increase germination.

For little bluestem, there was no treatment effect of leachate on radicle length (Mann-Whitney test: $U=5.0, n=12$, $\mathrm{p}=0.145)$ or shoot length $(\mathrm{U}=7.5, \mathrm{n}=12$, $\mathrm{p}=0.282)$. For Indian grass, there was a decrease in radicle length in response to leachate $(\mathrm{U}=11.50, \mathrm{n}=19, \mathrm{p}=0.005)$. However, there was no effect of treatment on shoot length $(\mathrm{U}=41.5 \mathrm{n}=19, \mathrm{p}=0.840)$. Black-eyed Susan showed no effect of treatment on radicle length $(\mathrm{U}=211.5, \mathrm{n}=42$, $\mathrm{p}=0.828$ ), but had a marginally significant effect of treatment on shoot length $(\mathrm{U}=145.5, \mathrm{n}=42, \mathrm{p}=0.052$ ).

Table 4 Percent germination in petri dishes under two treatments. See text for chi-square tests of treatment by species.

\begin{tabular}{llc}
\hline Treatment & Species & $\begin{array}{c}\text { Average percent } \\
\text { germination }\end{array}$ \\
\hline Control & little bluestem & $10.0 \pm 0.0$ \\
Control & Indian grass & $26.7 \pm 8.8$ \\
Control & inland sea-oats & $3.3 \pm 3.3$ \\
Control & partridge-pea & $3.3 \pm 3.3$ \\
Control & black-eyed Susan & $66.7 \pm 8.8$ \\
Leachate & little bluestem & $30.0 \pm 0.0$ \\
Leachate & Indian grass & $36.7 \pm 6.7$ \\
Leachate & inland sea-oats & $0.0 \pm 0.0$ \\
Leachate & partridge-pea & $10.0 \pm 5.8$ \\
Leachate & black-eyed Susan & $73.3 \pm 6.7$ \\
\hline
\end{tabular}

\section{DISCUSSION}

In general, there were few effects of the application of redcedar leachate and/or litter. Treatment with leachate and/or litter did not hamper germination, and there was no clear effect of treatment on growth in the Cone-tainer experiments. There were weak trends suggesting in some cases that application of litter plus leachate might increase growth, but trends were weak. A negative effect of redcedar was not demonstrated over the months-long course of these experiments (56 d for fall 2016 and $77 \mathrm{~d}$ for spring 2017). There is some evidence from the petri-dish germination 
experiment that the redcedar leachate may stimulate germination rate (at least in Indian grass and little bluestem) but reduce growth of seedling root in Indian grass and seedling shoot in black-eyed Susan, but it is possible that the growth reductions are a short-lived effect.

Anecdotally, we observed that the treatment receiving the cedar leachate required more frequent watering in order to maintain the same moist environment as those receiving the water only. Further study of the rate of evaporation of the water and cedar leachate may provide additional insight regarding whether water resources may be affected by an eastern redcedar population. An additional anecdotal observation was that partridge-pea was susceptible to mold growth that was possibly inhibited by the redcedar leachate. A study of the allelopathic effects of cedar leachate on mold growth may provide additional data to test this observation.

We speculate that in soils with long exposure to redcedar litter (years rather than months), perhaps effects would be greater, or there might be a negative effect. We are considering future experiments planting seeds or seedlings within the driplines of existing cedars and comparing their growth to the growth of individuals away from the dripline.

It is also possible that Juniperus virginiana may lack the same allelopathic compounds found in the western junipers (e.g., Juniperus monosperma). It would be informative to repeat the experiment on a larger scale, comparing the effects of eastern redcedar, one-seeded juniper, and Utah juniper.

It is also possible that a harmful effect of redcedar is produced by shade; future research could include planting individuals at varying distances from the trunk of the tree to determine whether shading has an effect, or if the dripline of the tree has an effect. In future work, we plan to examine the $\mathrm{pH}$ of soils within the dripline and 3 and $5 \mathrm{~m}$ beyond the dripline of redcedars. Smith and Stubbendeick (1990) suggested that the effects of red-cedar on herbaceous species in the field is mainly mediated through light and water competition from the mature trees; they demonstrated reduction in biomass for prairie species grown inside the dripline of cedar trees. It is also possible that water competition is the mechanism of limitation; many of the studies showing reduced herbaceous growth under junipers (e.g., Schott and Pieper 1985; Yager and Smeins 1999) were conducted in climates drier than that of south-central Oklahoma and certainly under more water-limited conditions than our lab experiment. However, in northeastern Oklahoma, Engle et al. (1987) did demonstrate reduction in herbaceous standing crop within the dripline of redcedar trees. Van Els et al. (2010) demonstrated reduced species richness in forest understory under Juniperus trees in Oklahoma; they attributed these changes to increased litter depth but did not separate what chemical or physical characteristic of the litter served as a barrier to plant germination and growth. Finally, we plan to conduct a field experiment to determine whether the greater stress of growth outdoors or over a longer time is sufficient to show effects.

\section{ACKNOWLEDGMENTS}

We thank the Oklahoma Native Plant Society for providing a small grant to E.A.C. to purchase seeds and equipment for this study. We thank Tom and Charlene Tucker for allowing us to cut redcedar branches on their pasture land. We thank Matt Spears for his assistance in setting up the second run of this experiment. We also thank two anonymous reviewers for comments that led to improvement of this paper. 


\section{LITERATURE CITED}

Alford, A.L., E.C. Hellgren, R. Limb, and D.M. Engle. 2012. Experimental tree removal in tallgrass prairie: variable responses of flora and fauna along a woody cover gradient. Ecological Applications 22:947-958.

Engle, D.M., J.F. Stritzke, and P.L. Claypool. 1987. Herbage standing crop around eastern redcedar trees. Journal of Range Management 48:100-107.

Holthuizen, A.M.A. and T.L. Sharik. 1984. Seed longevity and mechanism of regeneration of eastern red cedar (Juniperus virginiana L.). Journal of the Torrey Botanical Society 111:153-158.

Horman, C.S. and V.J. Anderson. 2003. Understory response to Utah juniper litter. Journal of Range Management 56:6871.

IBM Corp. Released 2011. IBM SPSS Statistics for Windows, Version 20.0. Armonk, NY: IBM Corp.

Limb, R.F., D.M. Engle, A.L. Alford, and E.C. Hellgren. 2010. Tallgrass prairie plant community dynamics along a canopy cover gradient of eastern redcedar (Juniperus virginiana L.). Rangeland Ecology and Management 63:638644.

Linneman, J.S., M.S. Allen, and M.W. Palmer. 2011. The effects of removal of Juniperus virginiana L. trees and litter from a central Oklahoma grassland. Oklahoma Native Plant Record 11:43-60.
Pierce, A.M and P.B. Reich. 2010. The effects of eastern red cedar (Juniperus virginianus) invasion and removal on a dry bluff prairie ecosystem. Biological Invasions 12:241-252.

Schott, M.R. and R.D. Pieper. 1985. Influence of canopy characteristics of one-seed juniper on understory grasses. Journal of Range Management 38:328-331.

Smith, S.D. and J. Stubbendieck. 1990. Production of tall-grass prairie herbs below eastern redcedar. Prairie Naturalist 22:12-18.

Stipe, D.J. and T.B. Bragg. 1989. Effect of eastern red cedar on seedling establishment of prairie plants. Proceedings of the Eleventh North American Prairie Conference. pp. 101-102.

[USDA, SCS] United States Department of Agriculture, Soil Conservation Service. 1978. Soil Survey of Bryan County, Oklahoma. In cooperation with the Oklahoma Agricultural Experiment Station.

Van Els, P., R.E. Will, M.W. Palmer, and K.R. Hickman. 2010. Changes in forest understory associated with Juniperus encroachment in Oklahoma, USA. Applied Vegetation Science 12:346-368.

Yager, L.Y. and F.E. Smeins. 1999. Ashe juniper canopy and litter effects on understory vegetation in a juniper-oak savannah. Southwestern Naturalist 44:6-16. 